\title{
Aplikasi Web Commerce sebagai Ruang Praktik Mahasiswa dalam Berwirausaha
}

\author{
Marsinah Dewi Feiyska Nasution*1, Muhammad Giatman ${ }^{2}$, Ernawati Nazar 3 \\ 1,2,3 Program Studi Magister Pendidikan Teknologi dan Kejuruan, Universitas Negeri Padang \\ email: feiyskanasution@unp.ac.id*1, giatman@ ft.unp.ac.id ${ }^{2}$, ernawatiunp44@gmail.com ${ }^{3}$
}

(Received: 4 Agustus 2021/ Accepted: 8 Agustus 2021/ Published Online: 20 Desember 2021)

\begin{abstract}
Abstrak
Kewirausahaan merupakan salah satu mata kuliah yang wajib diambil oleh mahasiswa Universitas Negeri Padang (UNP), termasuk mahasiswa dari Fakultas Pariwisata dan Perhotelan. Mahasiswa terkadang kurang tertarik dan termotivasi dalam mengikuti mata kuliah kewirausahaan dalam segi praktiknya karena masih hanya menggunakan cara konvensional. Tujuan dari penelitian ini adalah membuat aplikasi web commerce yang akan digunakan oleh mahasiswa sebagai ruang praktik berwirausaha. Metode dalam pembuatan aplikasi ini menggunakan model waterfall dengan metode SLDC atau pendekatan alur hidup perangkat lunak yang sederhana. Aplikasi web commerce yang dihasilkan kemudian diuji menggunakan pengujian black box untuk mengetahui keberhasilan dari alur yang telah dirancang, dan hasil pengujian menunjukkan bahwa aplikasi tersebut dapat berjalan dengan baik. Hasil dari penelitian ini adalah sebuah aplikasi e-commerce berbasis web dinamis dengan menggunakan bahasa pemrograman PHP, osCommerce Content Management System (CMS), dan database MySQL. Aplikasi ini dapat menjadi solusi dari permasalahan metode wirausaha konvensional serta dapat membuat mahasiswa yang mengikuti mata kuliah kewirausahaan menjadi lebih tertarik dalam praktik berwirausaha.
\end{abstract}

Kata kunci: Aplikasi, Kewirausahaan, E-commerce, Mahasiswa, CMS.

\begin{abstract}
Entrepreneurship is one of the subjects that must be taken by students of Universitas Negeri Padang $(U N P)$, including students from Faculty of Tourism and Hospitality. Students sometimes have less interest and motivate in taking entrepreneurship courses in practice because they still only use conventional methods. The purpose of this research is to create a web commerce application that will be used by students as an entrepreneurship practices space. The method that used in making this application is the waterfall model with the SLDC method or a simple software life flow approach. Web commerce application that produced then tested using black box to find out the success of the flow that has been designed, and the black box test results show that the application can run well. The result of this research is a dynamic web-based e-commerce application using the PHP programming language, osCommerce Content Management System (CMS), and MySQL database. This application can be a solution to the problems of conventional entrepreneurial methods and can make students who take entrepreneurship courses more interested in entrepreneurship practices.
\end{abstract}

Keywords: Application, Entrepreneurship, E-commerce, Student, CMS.

\section{PENDAHULUAN}

Kewirausahaan merupakan salah satu mata kuliah yang wajib diambil oleh mahasiswa yang kuliah di Universitas Negeri Padang (UNP), termasuk mahasiswa Fakultas Pariwisata dan Perhotelan (FPP). Kewirausahaan adalah suatu kemampuan yang dimiliki seseorang dalam melihat berbagai peluang serta keterbukaan dalam menerima segala masukan juga perubahan positif yang bisa membuat bisnis semakin berkembang (Saragih, 2017). Wirausaha secara etimologis berasal dari kata wira dan usaha. Wira berarti berani dan usaha berarti usaha yang terkait dengan fisik dan pikiran untuk memperoleh sesuatu yang diinginkan. Sedangkan 
wirausaha secara terminologis berarti kemampuan dalam mencari, menciptakan, serta memanfaatkan peluang mencapai apa yang diinginkan secara ideal. lstilah wirausaha dekat dengan istilah wiraswasta, meskipun ada beberapa perbedaan. Wirausaha lebih kepada jiwa serta semangat lalu direalisasikan dalam seluruh aspek kehidupan, sedangkan wiraswasta lebih berfokus kepada objek. Jadi, perbedaan wiraswastawan dengan wirausahawan yaitu wirausaha lebih cenderung bertindak dengan tantangan dan risiko. Maksudnya, wiraswastawan cenderung mengandalkan modal yang ada untuk membuat sebuah usaha, sedangkan wirausahawan bertindak dengan memanfaatkan peluang. Wiraswastawan belum tentu wirausahawan, akan tetapi wirausahawan bisa jadi sekaligus wiraswastawan (Ananda \& Rafida, 2016).

Teknologi yang semakin berkembang secara signifikan membuat masyarakat semakin mudah untuk melakukan berbagai kegiatan, termasuk penggunaan internet dalam memperoleh atau memproses informasi melalui sebuah sistem informasi. Sistem informasi merupakan sebuah sistem buatan manusia yang terdiri dari beberapa komponan dalam suatu organisasi untuk menyajikan informasi (Ladjamudin, 2013). Dampak positif yang bisa dirasakan melalui internet yaitu penggunaannya sebagai media penjualan yang bisa menjadikan lebih luasnya sistem pemasaran (Kasmi \& Candra, 2017).

Teknologi informasi memiliki pengaruh yang sangat besar dalam memajukan sebuah usaha. Banyak cara untuk mempromosikan sebuah usaha yang dimiliki, misalnya dengan menggunakan website e-commerce, yang merupakan kegiatan jual beli secara online melalui website (Handayani, 2018). Dalam dunia bisnis, situs web e-commerce harus dimiliki oleh setiap perusahaan yang ingin memperluas operasinya, karena e-commerce menawarkan berbagai manfaat. Konsumen tidak perlu pergi ke toko secara langsung untuk memilih barang yang ingin mereka beli, dan perusahaan dapat menyelesaikan transaksi jual beli setiap saat. Konsumen bisa lebih sedikit dalam mengeluarkan biaya serta pengusaha juga bisa menghemat biaya untuk promosi. Jika toko berada di lokasi yang jauh, konsumen tidak perlu mengeluarkan ongkos untuk pergi menuju toko, akan tetapi diganti dengan ongkos kirim yang lebih murah, dan juga pengusaha dapat mempromosikan usahanya hingga kemana pun (Maulana et al., 2015). Dalam beberapa tahun terakhir, penggunaan komputer di bidang pemasaran dan penjualan menjadi lebih umum. Karena internet, pemasaran dan penjualan dapat dilakukan kapanpun dan dimanapun dengan nyaman, tanpa memperdulikan ruang dan waktu. $E$ commerce adalah aplikasi internet paling dasar dalam bidang bisnis dan perdagangan (Nuryanti, 2013).

Mahasiswa terkadang kurang tertarik dan termotivasi dalam mengikuti mata kuliah kewirausahaan dalam segi praktiknya karena masih hanya menggunakan cara konvensional. Cara berwirausaha mahasiswa yang masih konvensional tersebut merupakan tolak ukur dari pembuatan aplikasi web commerce atau e-commerce ini. Aplikasi $e$-commerce ini bisa menjadi tantangan baru sekaligus solusi untuk persaingan secara sehat antara para pengusaha pemula termasuk dari kalangan mahasiswa, agar dapat membantu mereka dalam menciptakan lapangan pekerjaan sendiri. Untuk mencapai tujuan dari kegiatan berwirausaha ini, maka dibuatlah aplikasi e-commerce yang berperan sebagai sebuah ruang praktik serta bekal pertama bagi mahasiswa dalam memulai kegiatan wirausaha mereka.

E-commerce adalah pengikutsertaan jaringan komputer dalam peningkatan kinerja, profitabilitas, dan layanan pelanggan dalam organisasi, perolehan pangsa pasar, serta pengiriman produk dengan cepat. E-commerce melibatkan semua aspek dalam interaksi elektronik pada organisasi perusahaan stakeholder, terdapat juga kegiatan seperti perancangan sebuah website dalam mendukung hubungan antar investor. Singkatnya, e-commerce mengikutsertakan teknologi informasi dalam peningkatan komunikasi serta transaksi dari seluruh yang terlibat dalam organisasi (Nirmala \& Musyafa, 2017).

Pembuatan aplikasi ini menggunakan Content Management System (CMS). CMS adalah sebuah aplikasi yang menggunakan berbagai tema dalam persiapannya, seperti tema $e$ - 
commerce. Melalui e-commerce, sistem jual-beli manual bisa berubah jadi terkomputerisasi. Dengan keberadaan CMS e-commerce, proses pemesanan dapat menjadi lebih mudah yang mengakibatkan peningkatan penjualan (Randa et al., 2015). Bahasa pemrograman yang digunakan yaitu PHP Hypertext Processor. PHP adalah sebuah bahasa script berbasis server (server-side) yang dapat menguraikan kode web menjadi kode php dengan menggunakan ekstensi .php, yang akhirnya menghasilkan tampilan website yang terlihat dinamis di sisi client (browser). Ini juga dapat menjadikan halaman HTML menjadi lebih maksimal, dinamis, serta bisa digunakan menjadi aplikasi yang lebih lengkap, contohnya e-learning, e-portal, e-library, dan sebagainya melalui penambahan script PHP (Sari \& Abdilah, 2019). Database yang digunakan untuk menyimpan data pada aplikasi ini yaitu MySQL. MySQL merupakan nama server database yang berperan dalam penanganan database. Database merupakan pengorganisasian beberapa data yang bertujuan untuk mempermudah dalam menyimpan dan mengakses data. Kita dapat menyimpan dan mengakses data dengan cara cepat dan mudah dengan mengggunakan MySQL. MySQL termasuk database yang relasional, data diperlihatkan dalam bentuk 2 dimensi yang dinamakan dengan tabel yang tersusun dari baris serta kolom (Kadir, 2013).

Mengacu pada hasil penelitian yang sebelumnya dilakukan oleh Cahyanti et al., (2021) yang membahas tentang perancangan e-commerce untuk memasarkan produk dari sebuah UKM yang memproduksi kerajinan bambu dengan menggunakan metode waterfall yang memeri kemudahan terhadap penjualan produk oleh UKM tersebut, penelitian yang juga dilakukan oleh (Syahriani, 2017) yang menerapkan e-commerce untuk menangani serta memperoses data produk, dan memasarkan produk perlengkapan bayi. Selain itu, penelitian lain yang dilakukan oleh Fadhlurrahman \& Capah, (2020) yang membuat sebuah aplikasi berbasis web untuk menyewa lapangan futsal yang melakukan black box testing dalam menguji aplikasinya.

Berdasarkan hal tersebut, maka penelitian ini bertujuan untuk merancang serta membuat sebuah aplikasi e-commerce sebagai suatu ruang praktik serta bekal pertama bagi mahasiswa dalam memulai kegiatan wirausaha mereka, serta sebagai motivasi bagi mereka untuk bisa mengembangkan usaha secara nyata.

\section{METODE}

Metode yang digunakan dalam pembuatan sistem ini adalah adalah waterfall. Waterfall merupakan metode SLDC atau pendekatan alur hidup perangkat lunak yang sederhana (Sukamto \& Shalahuddin, 2015). Pendekatan metode waterfall adalah sistematis dan berurut dimulai dari level kebutuhan sistem, kemudian lanjut ke tahap analisis, tahap desain, tahap pengodean, tahap pengujian, dan tahap pemeliharaan (Muharto \& Ambarita, 2016).

Pada analisis kebutuhan, dilakukan pengumpulan data dengan tujuan untuk memahami software yang diharapkan dan apa yang tidak bisa ada di dalam software tersebut, dalam penelitian ini mengumpulkan data melalui studi literatur dan juga observasi. Desain akan dilakukan setelah informasi diperoleh dari tahap sebelumnya, kemudian akan dipertimbangkan dan dilakukan perancangan. Tahap pengodean dilakukan sesuai desain yang telah ditentukan, sistem terintegrasi dengan sintak untuk menghasilkan sebuah sistem informasi yang diharapkan, sistem ini dirancang menggunakan sebuah Content Management System (CMS) yaitu osCommerce, database yang digunakan dalam percancangan sistem ini adalah MySQL, bahasa pemrograman menggunakan PHP, serta web server menggunakan XAMPP. Setelah sistem selesai dibuat, maka akan dilakukan pengujian untuk memastikan sistem sudah dapat berjalan dengan alur yang telah dirancang, pada penelitian ini, pengujian dilakukan dengan black box testing. Jika sistem telah bisa digunakan dan berjalan dengan baik, maka perlu dilakukan pemeliharaan guna menjaga kualitas sistem dan mengupgradenya. Tahap penelitian 
dan pengembangan dengan metode waterfall yang telah dijelaskan tersebut tampak seperti pada gambar 1.

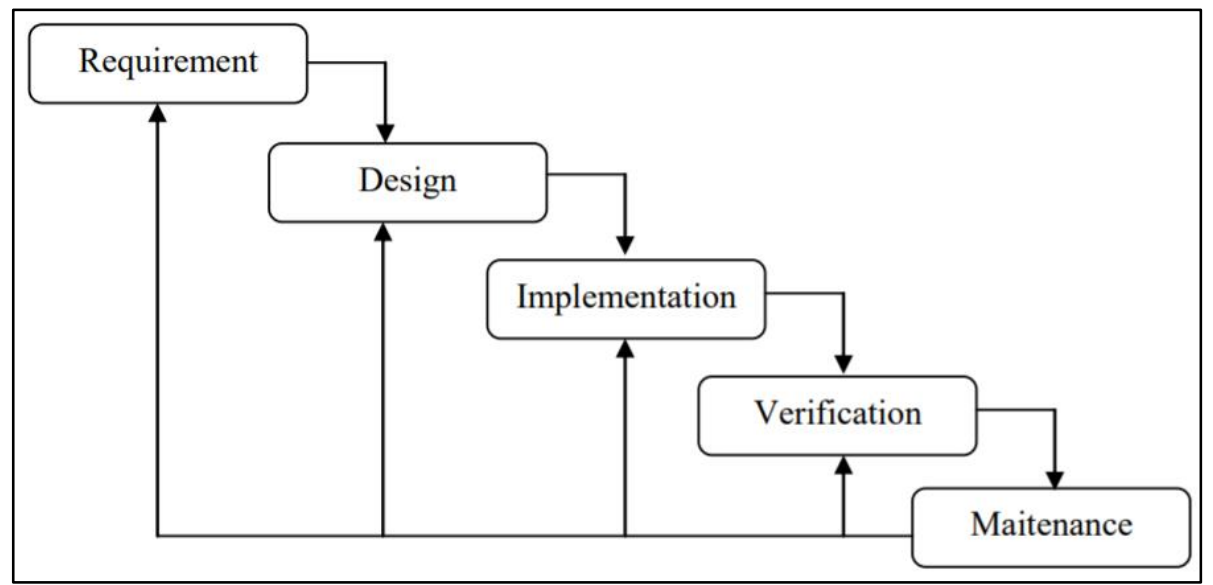

Gambar 1. Model waterfall

\section{HASIL DAN PEMBAHASAN}

Hasil

Berdasarkan tujuan penelitian, maka penelitian ini menghasilkan sistem informasi $e$ commerce dinamis yang dapat mendukung praktik wirausaha mahasiswa pada mata kuliah kewirausahaan. Gambar 2 memperlihatkan tampilan halaman utama untuk umum.

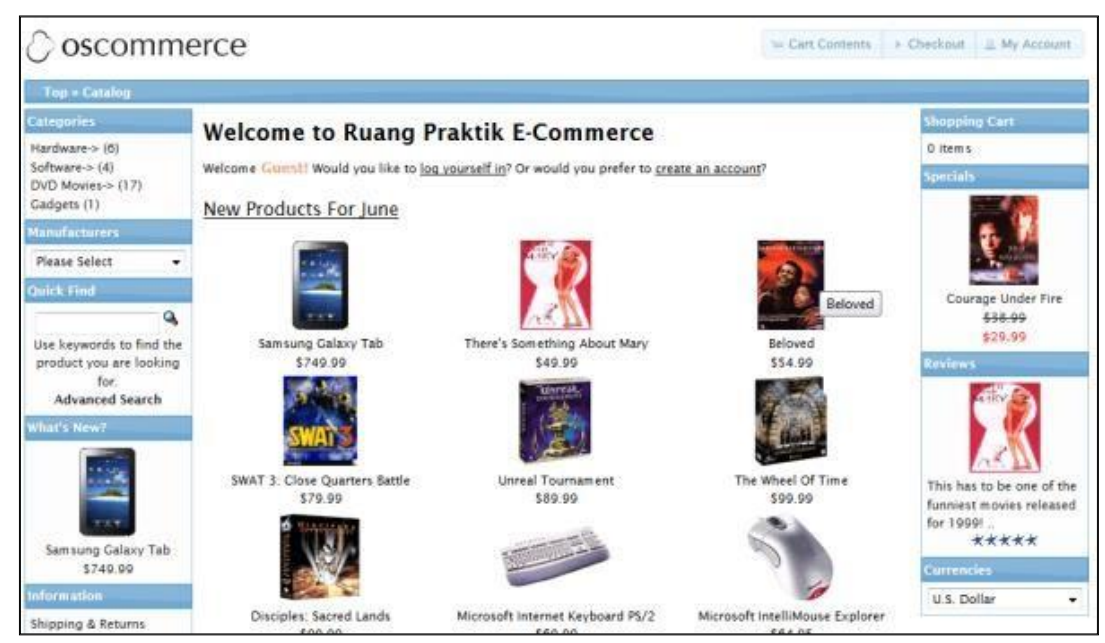

Gambar 2. Tampilan halaman utama untuk umum

Halaman utama untuk umum merupakan halaman yang muncul pertama kali pada saat aplikasi diakses, halaman ini terdiri atas beberapa jenis menu yang bisa diakses oleh siapa pun. Halaman pendaftaran pengguna yang terlihat pada gambar 3 merupakan tempat untuk mendaftar sebagai pelanggan agar dapat bertransaksi pada aplikasi ini. Selanjutnya, halaman login admin yang terlihat pada gambar 4 dibuat khusus dan hanya administrator yang dapat mengaksesnya, halaman bisa diakses dengan cara memilih menu admin pada halaman utama untuk umum. Saat admin berhasil masuk, maka akan tampil halaman seperti terlihat pada gambar 5 . 


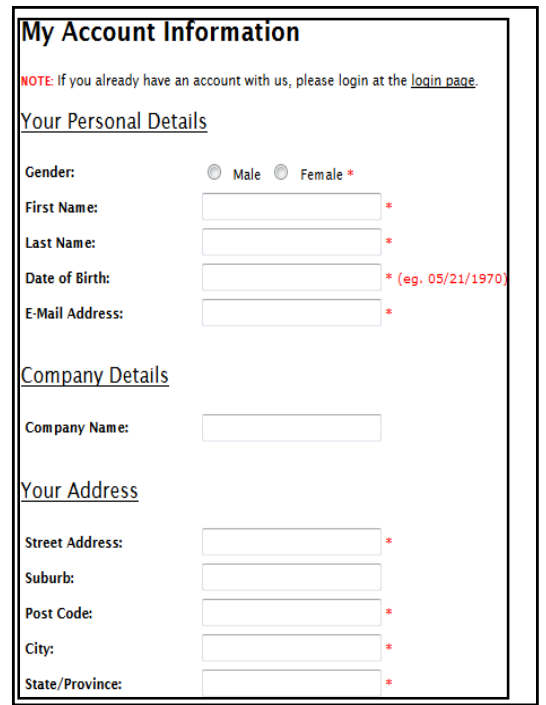

Gambar 3. Halaman Pendaftaran Pengguna

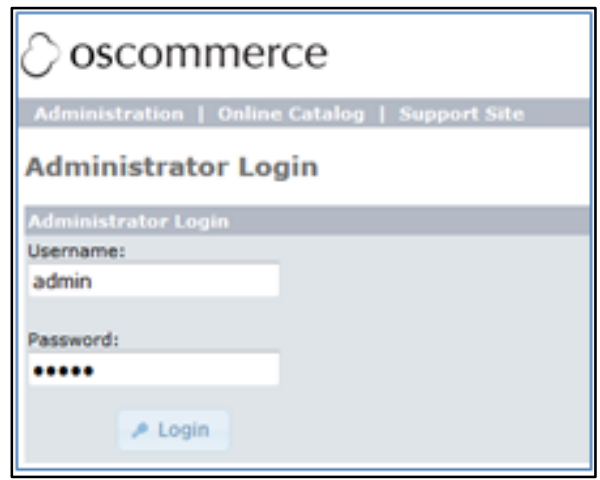

Gambar 4. Halaman Login Admin

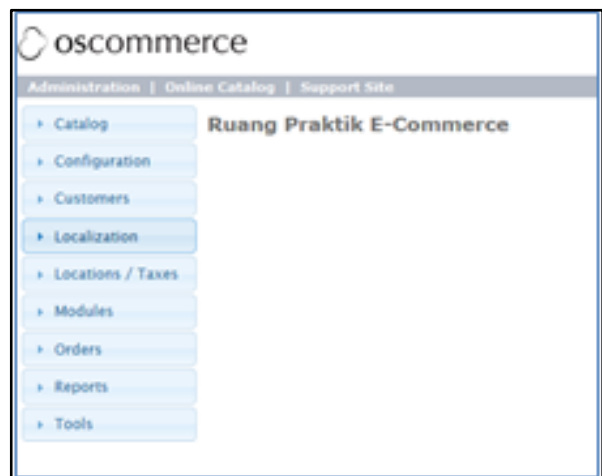

Gambar 5. Halaman Utama untuk Admin

Admin dapat melakukan pengaturan untuk aplikasi ini, seperti pengaturan katalog, pelanggan, pembelian, dan lainnya. Gambar 6 menampilkan halaman penambahan kategori yang berguna untuk membuat beberapa kategori sesuai jenis barang yang ada agar tertata dengan rapi sebelum diterbitkan. Sementara itu, halaman penambahan modul seperti yang terlihat pada gambar 7 yang digunakan dalam penambahan fitur aplikasi ini sesuai kebutuhan. Sementara itu, gambar 8 menampilkan halaman data transaksi pelanggan, halaman ini bisa dilihat setelah pelanggan melakukan pemilihan produk yang ada ke dalam keranjang belanja. 


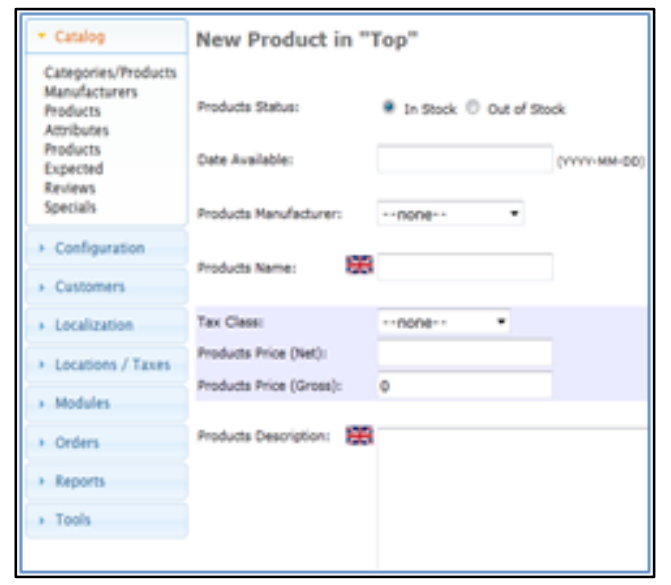

Gambar 6. Halaman Penambahan Kategori

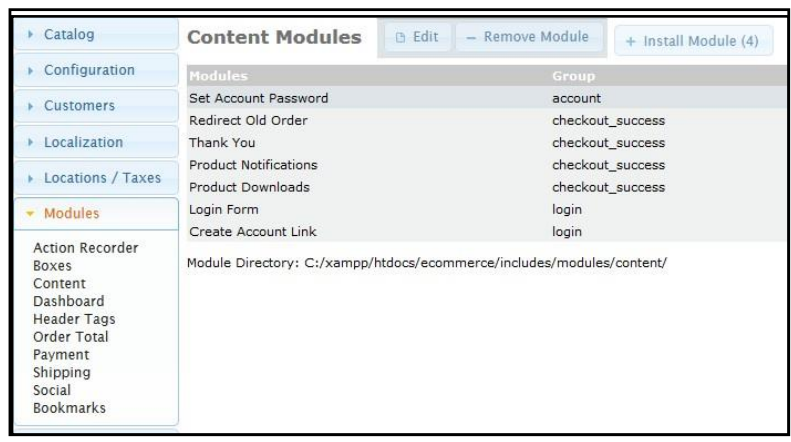

Gambar 7. Halaman Penambahan Modul

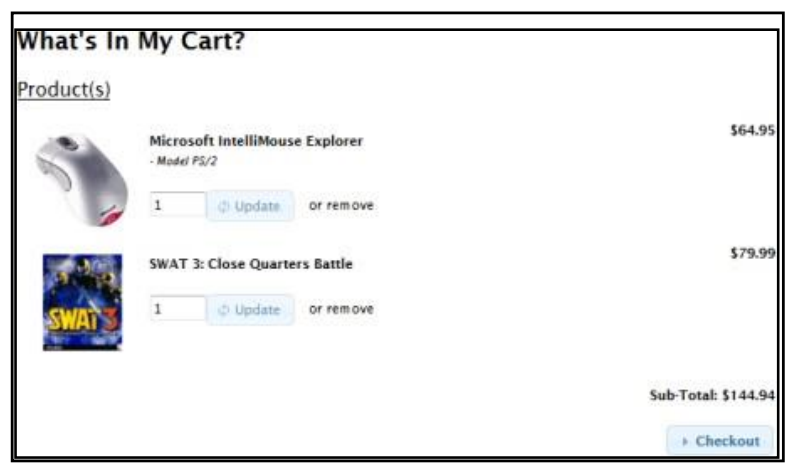

Gambar 8. Halaman Data Transaksi Pelanggan

\section{Pembahasan}

E-commerce merupakan sebuah aplikasi website dinamis. Penilitian ini menghasilkan sebuah aplikasi $e$-commerce berbasis web (web commerce) yang bisa digunakan sebagai ruang praktik mahasiswa dalam mengikuti mata kuliah kewirausahaan. Terlihat pada gambar 2 sampai gambar 8 merupakan user interface pada aplikasi web commerce ini. Pengguna bisa melihat barang apa saja yang tersedia di aplikasi tanpa perlu melakukan login. Pelanggan harus mendaftar terlebih dahulu untuk mendapatkan username serta password yang kemudian digunakan untuk login ke dalam sistem agar pelanggan dapat melakukan transaksi atau pembelian produk. Pelanggan bisa memasukkan produk ke dalam keranjang belanja dan melanjutkan ke pembayaran untuk diproses transaksinya. Admin juga harus login agar dapat mengelola seluruh data yang ada pada sistem, meliputi data produk, pengguna, dan sebagainya.

Pengujian aplikasi web commerce yang telah dihasilkan dilakukan pengujian dengan metode pengujian black box. Black box testing merupakan pengujian yang berfokus kepada 
persyaratan fungsional dari sebuh software atau perangkat lunak (Pressman, 2010). Metode pengujian black box dilakukan guna meminimalisir terhadap munculnya error atau kesalahan pada sistem serta memastikan output yang diperoleh telah sesuai dengan yang telah direncanakan di awal perancangan. Hasil dari pengujian black box yang telah dilakukan terlihat pada tabel 1.

Tabel 1 Hasil Black Box Testing

\begin{tabular}{cccc}
\hline Komponen & Skenario Pengujian & $\begin{array}{c}\text { Hasil yang } \\
\text { Diharapkan }\end{array}$ & $\begin{array}{c}\text { Hasil } \\
\text { Pengujian }\end{array}$ \\
\hline $\begin{array}{c}\text { Pendaftaran Akun } \\
\text { Pelanggan }\end{array}$ & $\begin{array}{c}\text { Menu pendaftaran akun } \\
\text { pelanggan diakses } \\
\text { Menu login diakses, }\end{array}$ & $\begin{array}{c}\text { Halaman pendaftaran } \\
\text { akun pelanggan tampil }\end{array}$ & Berhasil \\
$\begin{array}{c}\text { Login Admin dan } \\
\text { Pelanggan }\end{array}$ & $\begin{array}{c}\text { Hername dan password } \\
\text { diinput }\end{array}$ & $\begin{array}{c}\text { login berhasil } \\
\text { Mernin }\end{array}$ & Berhasil \\
Menu Penambahan & Menu penambahan & Halaman penambahan & Berhasil \\
Modul & modul diakses & modul tampil & Halaman penambahan \\
Menu Penambahan & Menu penambahan & Berhasil \\
Kategori & kategori diakses & kategori tampil & Halaman transaksi \\
Menu Transaksi & Menu transaksi & Berhasil \\
Pelanggan & pelanggan diakses & pelanggan tampil & Berhasil \\
\hline
\end{tabular}

Hasil pengujian black box menunjukkan bahwa komponen-komponen yang diuji berhasil berjalan sesuai yang diharapkan. Komponen-komponen tersebut berfokus pada menu pendaftaran, menu login, menu pernambahan modul, menu penambahan kategori, serta menu transaksi pelanggan. Hasil ini sesuai dengan hasil temuan pada penelitian sebelumnya oleh (Afuan, Nofiyati, \& Umayah, 2021; Anggoro, \& Hidayat, 2020; Rizki, \& Mulyati, 2020), bahwa produk atau sistem mereka sudah dengan hasil telah telah diujikan, dan dapat digunakan sebagaimana mestinya

\section{SIMPULAN}

Berdasarkan hasil penelitian serta pembuatan aplikasi web commerce sebagai ruang praktik mahasiswa dalam mata kuliah kewirausahaan, maka dari penelitian ini dapat disimpulkan bahwa keberadaan aplikasi web commerce dapat menjadi solusi dari permasalahan metode wirausaha konvensional yang dilakukan oleh mahasiswa dalam mata kuliah kewirausahaan, sehingga mahasiswa akan lebih tertarik dalam praktik berwirausaha. Dengan adanya aplikasi ini dapat membantu mahasiswa dalam memulai usaha sendiri, serta akan mempermudah pelanggan untuk bertransaksi secara online.

\section{REFERENSI}

Afuan, L., Nofiyati, N., \& Umayah, N. (2021). Rancang Bangun Sistem Informasi Bank Sampah di Desa Paguyangan. Edumatic: Jurnal Pendidikan Informatika, 5(1), 21-30.

Ananda, R., \& Rafida, T. (2016). Pengantar Kewirausahaan Rekayasa Akademik Melahirkan Enterpreneurship. Medan: Perdana Publishing.

Anggoro, D., \& Hidayat, A. (2020). Rancang bangun sistem informasi perpustakaan sekolah berbasis web guna meningkatkan efektivitas layanan pustakawan. Edumatic: Jurnal Pendidikan Informatika, 4(1), 151-160.

Cahyanti, F. L. D., Fajar Sarasati, Widiastuti, \& Firasari, E. (2021). Perancangan E-Commerce Sebagai Media Pemasaran Kerajian Bambu. Edumatic: Jurnal Pendidikan Informatika, 5(1), 70-79. https://doi.org/10.29408/edumatic.v5i1.3275 
Fadhlurrahman, M. F. F., \& Capah, D. A. H. (2020). Aplikasi Penyewaan Lapangan Futsal Berbasis Web. Edumatic: Jurnal Pendidikan Informatika, 4(2), 30-39. https://doi.org/10.29408/edumatic.v4i2.2412

Handayani, S. (2018). Perancangan Sistem Informasi Penjualan Berbasis E-Commerce Studi Kasus Toko Kun Jakarta. ILKOM Jurnal Ilmiah, 10(2), 182-189. https://doi.org/10.33096/ilkom.v10i2.310.182-189

Kadir, A. (2013). Buku Pintar Programmer Pemula PHP. Yogyakarta: Mediakom.

Kasmi, K., \& Candra, A. N. (2017). Penerapan E-Commerce Berbasis Business To Consumers Untuk Meningkatan Penjualan Produk Makanan Ringan Khas Pringsewu. Jurnal AKTUAL, 15(2), 109-116. https://doi.org/10.47232/aktual.v15i2.27

Ladjamudin, A.-B. Bin. (2013). Analisis dan Desain Sistem Informasi. Yogyakarta: Graha Ilmu.

Maulana, S. M., Susilo, H., \& Riyadi. (2015). Implementasi E-Commerce Sebagai Media Penjualan Online. Jurnal Administrasi Bisnis, 29(1), 1-9.

Muharto, \& Ambarita, A. (2016). Metode Penelitian Sistem Informasi: Mengatasi Kesulitan Mahasiswa dalam Menyusun Proposal Penelitian (1st ed.). Yogyakarta: Deepublish.

Nirmala, E., \& Musyafa, A. (2017). Modul E-Commerce S1 Teknik Informatika Universitas Pamulang. Pamulang: UNPAM PRESS.

Nuryanti. (2013). Peran E-Commerce Untuk Meningkatkan Daya Saing Usaha Kecil dan Menengah ( UKM ). Jurnal Ekonomi Manajemen Ekonomi Universitas Riau, 21(4), 15.

Pressman, R. S. (2010). Rekayasa Perangkat Lunak: Pendekatan Praktisi (Buku 1) (7th ed.). Yogyakarta: Andi.

Randa, M. A., Wijaya, A., Universitas, M., Darma, B., \& Bina, D. U. (2015). Perancangan Dan Pembuatan Content Management System (CMS) dengan Tema E-Commerce Berbasis Multi-Device. Bina Darma E-Journal, 1-8.

Rizki, R., \& Mulyati, S. (2020). Implementasi One Time Password Menggunakan Algoritma SHA-512 Pada Aplikasi Penagihan Hutang PT. XHT. Edumatic: Jurnal Pendidikan Informatika, 4(1), 111-120.

Saragih, R. (2017). Membangun Usaha Kreatif,Inovatif dan Bermanfaat Melalui Penerapan kewirausahaan. Jurnal Kewirausahaan, 3(2), 26-34.

Sari, A. O., \& Abdilah, A. (2019). Web Programming. Yogyakarta: Graha Ilmu.

Sukamto, R. A., \& Shalahuddin, M. (2015). Rekayasa Perangkat Lunak Terstruktur dan Berbasis Objek. Bandung: Informatika.

Syahriani. (2017). Penerapan Sistem Informasi E-Commerce Pakaian dan Perlengkapan Bayi. Jurnal Teknik Komputer AMIK BSI (JTK), III(2), 77-82. 